Review

\title{
Hypericum japonicum Thunb. ex Murray: Phytochemistry, Pharmacology, Quality Control and Pharmacokinetics of an Important Herbal Medicine
}

\section{Lin-Sheng Liu ${ }^{1}$, Meng-Hua Liu ${ }^{2}$ and Jing-Yu He ${ }^{3, *}$}

1 Department of Pharmacy, Foshan Hospital of Traditional Chinese Medicine, Foshan 528000, Guangdong, China; E-Mail: 1lsgqy@163.com

2 School of Pharmaceutical Sciences, Southern Medical University, Guangzhou 510515, Guangdong, China; E-Mail: menghua_liu@hotmail.com

3 Guangzhou Institute of Advanced Technology, Chinese Academy of Sciences, Guangzhou 511458, Guangdong, China

* Author to whom correspondence should be addressed; E-Mail: jy.he@giat.ac.cn; Tel: +86-20-2291-2733; Fax: +86-20-2291-2525.

Received: 6 June 2014; in revised form: 7 July 2014 / Accepted: 16 July 2014 /

Published: 24 July 2014

\begin{abstract}
Hypericum japonicum Thunb. ex Murray is mainly distributed throughout Asia, Oceania and North America and is used as an important herbal medicine. H. japonicum contains many valuable secondary metabolites, such as flavonoids, phloroglucinols and xanthones and has hepatoprotective, anti-tumor, antibacterial, antiviral, and antioxidant activities and effects on the cardiovascular system and immunity. Coupled with phytochemical and pharmacological research, a series of analytical methods have been developed to evaluate the quality of $H$. japonicum based on its bioactive components. A pharmacokinetics study involved the absorption of two main flavonoids of H. japonicum in rats. This review aims to present an up-to-date and comprehensive overview of the phytochemistry, pharmacology, quality control and pharmacokinetics of $H$. japonicum, which should be useful for the greater development of $H$. japonicum, especially in the development of new drugs and therapeutics for various diseases.
\end{abstract}

Keywords: Hypericum japonicum; phytochemistry; pharmacology; quality control; pharmacokinetics 


\section{Introduction}

Hypericum japonicum Thunb. ex Murray (Hypericaceae) is an annual herb mainly distributed throughout Asia, Oceania and North America [1,2]. In China, it is widely distributed in Liaoning Province, Shandong Province and other provinces in southern China where it grows in rice fields, ditches, marshes, grasslands and waste places where the altitude is below $2800 \mathrm{~m}[2,3]$.

H. japonicum called "Tian-Ji-Huang" or "Di-Er-Cao" in Chinese was first listed as a herbal medicine in "Sheng Cao Yao Xing Bei Yao" published during the Qi Dynasty. It has been used in Traditional Chinese Medicine for a long time for relieving internal heat or fever, hemostasis and detumescence [4]. In addition, it has also been used as a medicinal herb in Asian countries, such as Japan, South Korea, Thailand, Nepal, India, Vietnam and Philippines [2]. H. japonicum has been studied due to its high value in traditional medicine. The results of modern pharmacological studies have shown that $H$. japonicum could be used for the treatment of bacterial diseases, infectious hepatitis, acute and chronic hepatitis, gastrointestinal disorders, internal hemorrhages and tumors, which generally matches its traditional uses [4,5]. So far, no studies on the toxicity of $H$. japonicum have been reported.

Recently, different classes of chemicals such as flavonoids, xanthonoids, chromone glycosides, phloroglucinol derivatives and lactones have been found in this plant. Among these isolated components, some single flavonoid compounds such as quercitrin, isoquercitrin and quercetin-7-O- $\alpha$ L-rhamnose are shown to have a variety of bioactivities in vivo or in vitro, and thereby are thought as the bioactive components of $H$. japonicum. Hence, quality control based on these bioactive components to ensure the effects of $H$. japonicum materials and its related products is urgent and necessary. However, the quality control of $H$. japonicum is still not listed in the Chinese Pharmacopoeia (2010 edition) and other official pharmacopoeias. A number of studies have thus attempted to develop accurate, sensitive and selective analytical methods for qualitative and quantitative evaluation of $H$. japonicum.

Aiming to provide beneficial information for modern uses and scientific studies of H. japonicum, this review summarizes and evaluates the available phytochemical and bioactive properties of $H$. japonicum reported by the literature. Besides, the research progress in the quality evaluation and pharmacokinetics of $H$. japonicum are also presented.

\section{Phytochemistry}

The chemical composition of $H$. japonicum has been studied during the last few years due to the importance and availability of plant. The phytochemical studies on H. japonicum have resulted in the isolation of flavonoids, phloroglucinols and xanthones [6-20]. In addition, some compounds from other classes were also isolated from this species [6,7,21-24]. The isolated compounds (compounds 1-56) are summarized in Table 1 and their chemical structures are presented in Figures 1-4. 
Table 1. Compounds in H. japonicum.

\begin{tabular}{|c|c|c|c|}
\hline No. & Compounds & Classes & References \\
\hline 1 & Quercetin & Flavonoid & [6] \\
\hline 2 & Quercitrin & Flavonoid & [6] \\
\hline 3 & Isoquercitrin & Flavonoid & [7] \\
\hline 4 & Quercetin-7-O- $\alpha$-L-rhamnoside & Flavonoid & [7] \\
\hline 5 & Quercetin-3-O- $\alpha$-L-rhamnosyl $(1 \rightarrow 2)$-O- $\alpha$-L-rhamnoside & Flavonoid & [7] \\
\hline 6 & Rutin & Flavonoid & [8] \\
\hline 7 & Kaempferol & Flavonoid & [7] \\
\hline 8 & Kaempferol-7-O- $\alpha$-L-rhamnoside & Flavonoid & [7] \\
\hline 9 & 5,7,3',4'-Tetrahydroxy-3-methoxyflavone & Flavonoid & [9] \\
\hline 10 & Taxifolin-3,7-O- $\alpha$-L-dirhamnoside & Flavonoid & {$[10]$} \\
\hline 11 & Sarothranol & Flavonoid & [11] \\
\hline 12 & 7,8-(2",2"-Dimethylpyrano)-5,3',4'-trihydroxy-3-methoxyflavone & Flavonoid & [7] \\
\hline 13 & 3,5,7,3',5'-Pentahydroxyflavonol & Flavonoid & [9] \\
\hline 14 & Dihydrokaempferol & Flavonoid & [12] \\
\hline 15 & (2R,3R)-Dihydroquercetin-3,7-O- $\alpha$-L-dirhamnoside & Flavonoid & [7] \\
\hline 16 & (2R,3R)-Dihydroquercetin-7-O- $\alpha$-L-rhamnoside & Flavonoid & [7] \\
\hline 17 & $(2 \mathrm{R}, 3 \mathrm{R})$-Dihydroquercetin & Flavonoid & [7] \\
\hline 18 & 2,3-Trans-dihydro-3,5,4'-trihydroxyflavonol-7-O- $\alpha$-L-rhamnoside & Flavonoid & [7] \\
\hline 19 & 3,8"-Biapigenin & Flavonoid & [6] \\
\hline 20 & Japonicin A & Phloroglucinol & {$[13]$} \\
\hline 21 & Japonicin B & Phloroglucinol & {$[13]$} \\
\hline 22 & Japonicin C & Phloroglucinol & {$[13]$} \\
\hline 23 & Japonicin D & Phloroglucinol & [13] \\
\hline 24 & Sarothralen A & Phloroglucinol & {$[14]$} \\
\hline 25 & Sarothralen B & Phloroglucinol & {$[14]$} \\
\hline 26 & Sarothralen C & Phloroglucinol & {$[15]$} \\
\hline 27 & Sarothralen D & Phloroglucinol & {$[15]$} \\
\hline 28 & Saroaspidin A & Phloroglucinol & {$[16]$} \\
\hline 29 & Sarothralin G & Phloroglucinol & {$[17]$} \\
\hline 30 & Sarothralin & Phloroglucinol & {$[18]$} \\
\hline 31 & 4,6-Dimethyl-1-O-[ $\alpha$-L-rhamnosyl $(1 \rightarrow 6)-\beta$-D-glucosyl] multifidol & Phloroglucinol & {$[19]$} \\
\hline 32 & 1,5,6-Trihydroxyxanthone & Xanthone & [7] \\
\hline 33 & 1,3,5,6-Tetrahydroxy-4-prenylxanthone & Xanthone & [7] \\
\hline
\end{tabular}


Table 1. Cont.

\begin{tabular}{|c|c|c|c|}
\hline No. & Compounds & Classes & References \\
\hline 34 & 1,5-Dihydroxyxanthone-6-O- $\beta$-D-glucoside & Xanthone & [7] \\
\hline 35 & 1,3,5,6-Tetrahydroxyxanthonin & Xanthone & {$[20]$} \\
\hline 36 & 1,3,6,7-Tetrahydroxyxanthonin & Xanthone & {$[20]$} \\
\hline 37 & 1,3,5-Trihydroxyxanthone & Xanthone & [20] \\
\hline 38 & Isojacareubin & Xanthone & [7] \\
\hline 39 & Deoxyisojacareubin & Xanthone & [7] \\
\hline 40 & $\begin{array}{c}\text { 4',5'-Dihydro-1,5,6-trihydroxy-4',4',5'-trimethylfurano }\left(2^{\prime} 3^{\prime}: 4,5\right) \\
\text { xanthone }\end{array}$ & Xanthone & [7] \\
\hline 41 & Bijaponicaxanthone & Xanthone & [7] \\
\hline 42 & 5,7-Dihydroxy-2-isopropyl-chromone-8- $\beta$-D-glucoside & Chromone & [7] \\
\hline 43 & 5,7-Dihydroxy-2-(1-methylpropyl) chromone-8- $\beta$-D-glucoside & Chromone & [7] \\
\hline 44 & Sarolactone & Chromone & {$[21]$} \\
\hline 45 & Stigmasterol & Triterpene & [6] \\
\hline 46 & Stigmasterol-3-O- $\beta$-D-glucoside & Triterpene & [6] \\
\hline 47 & Betulinic acid & Triterpene & [6] \\
\hline 48 & Chlorogenic acid & Phenolic acid & {$[12]$} \\
\hline 49 & Vanillic acid & Phenolic acid & [22] \\
\hline 50 & 3,4-Dihydroxybenzoic acid & Phenolic acid & {$[23]$} \\
\hline 51 & Octadecyl caffeate & Phenol & {$[23]$} \\
\hline 52 & $\begin{array}{l}\text { 2-Acetyl-3,5-dihydroxy-1-geranoxy-6-methyl-4-(2- } \\
\text { methyl)butyryl-benzene }\end{array}$ & Phenol & [24] \\
\hline 53 & $(-)$-Epicatechin & Phenol & {$[23]$} \\
\hline 54 & Flavesone & Ketone & {$[24]$} \\
\hline 55 & 9-Geranyl- $\alpha$-terpineol & Alcohol & {$[24]$} \\
\hline 56 & $\beta$-Sitosterol & Sterol & {$[23]$} \\
\hline
\end{tabular}

\subsection{Flavonoids}

Flavonoids are very common and important secondary metabolites in Nature. So far, nineteen flavonoids have been found in H. japonicum, including quercetin (1), quercitrin (2), isoquercitrin (3),

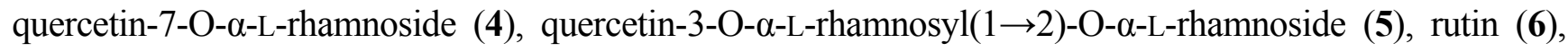
kaempferol (7), kaempferol-7-O- $\alpha$-L-rhamnoside (8), 5,7,3',4'-tetrahydroxy-3-methoxyflavone (9), taxifolin-3,7-O- $\alpha$-L-dirhamnoside (10), sarothranol (11), 7,8-(2",2"-dimethylpyrano)-5,3',4'-trihydroxy3-methoxyflavone (12), 3,5,7,3',5'-pentahydroxyflavonol (13), dihydrokaempferol (14), (2R,3R)dihydroquercetin-3,7-O- $\alpha$-L-dirhamnoside (15), $(2 R, 3 R)$-dihydroquercetin-7-O- $\alpha$-L-rhamnoside (16), 
(2R,3R)-dihydroquercetin (17), 2,3-trans-dihydro-3,5,4'-trihydroxyflavonol-7-O- $\alpha$-L-rhamnoside (18) and 3,8"-biapigenin (19) (Figure 1).

Figure 1. Chemical structures of flavonoids 1-19 from $H$. japonicum.<smiles>[R20]c1cc(O)c2c(=O)c(O)c(-c3ccc(O)c([Y9])c3)oc2c1</smiles>

1. Quercetin, $\mathrm{R}^{1}=\mathrm{R}^{2}=\mathrm{H}, \mathrm{R}^{3}=\mathrm{OH}$

2. Quercitrin, $\mathrm{R}^{1}=\mathrm{Rha}, \mathrm{R}^{2}=\mathrm{H}, \mathrm{R}^{3}=\mathrm{OH}$

3. Isoquercitrin, $\mathrm{R}^{1}=\mathrm{Glc}, \mathrm{R}^{2}=\mathrm{H}, \mathrm{R}^{3}=\mathrm{OH}$

4. Quercetin-7-O- $\alpha$-L-rhamnoside, $\mathrm{R}^{1}=\mathrm{H}, \mathrm{R}^{2}=\mathrm{Rh}, \mathrm{R}^{3}=\mathrm{OH}$

5. Quercetin-3-O- $\alpha$-L-rhamnosyl $(1 \rightarrow 2)$-O- $\alpha$-L-rhamnoside, $R^{1}=\mathrm{Rha}(1 \rightarrow 2) \mathrm{Rha}, \mathrm{R}^{2}=\mathrm{H}, \mathrm{R}^{3}=\mathrm{OH}$

6. Rutin, $\mathrm{R}^{1}=\mathrm{Rha}(1 \rightarrow 6) \mathrm{Glc}, \mathrm{R}^{2}=\mathrm{H}, \mathrm{R}^{3}=\mathrm{OH}$

7. Kaempferol, $\mathrm{R}^{1}=\mathrm{R}^{2}=\mathrm{R}^{3}=\mathrm{H}$

8. Kaempferol-7-O- $\alpha$-L-rhamnoside, $\mathrm{R}^{1}=\mathrm{R}^{3}=\mathrm{H}, \mathrm{R}^{2}=\mathrm{Rha}$

9. 5,7,3',4'-Tetrahydroxy-3-methoxyflavone, $\mathrm{R}^{1}=\mathrm{CH}_{3}, \mathrm{R}^{2}=\mathrm{H}, \mathrm{R}^{3}=\mathrm{OH}$

10. Taxifolin-3, 7-O- $\alpha$-L-dirhamnoside, $R^{1}=R^{2}=R h a, R^{3}=O H$<smiles>COc1c(-c2ccc(O)c(O)c2)oc2cc3c(c(O)c2c1=O)C=CC(C)(C)O3</smiles>

11. Sarothranol<smiles>O=C1c2c(O)cc(O)cc2OC(c2cc(O)cc(O)c2)C1O</smiles>

13. 3,5,7,3',5'-Pentahydroxyflavonol<smiles>COc1c(-c2ccc(O)c(O)c2)oc2c3c(cc(O)c2c1=O)OC(C)(C)C=C3</smiles>

12. 7,8-(2",2"-Dimethylpyrano)-5,3',4'-trihydroxy-3methoxyflavone<smiles>O=c1cc(-c2ccc(O)c(-c3c(O)cc(O)c4c(=O)cc(-c5ccc(O)cc5)oc34)c2)oc2cc(O)cc(O)c12</smiles>

19. 3,8"-Biapigenin 
Figure 1. Cont.<smiles>[R20]c1cc(O)c2c(c1)O[C@H](c1ccc(O)c([125I])c1)[C@H](O)C2=O</smiles>

14. Dihydrokaempferol, $R^{1}=R^{2}=R^{3}=H$

15. (2R, 3R)-Dihydroquercetin-3, 7-O- $\alpha$-L-dirhamnoside, $R^{1}=R^{2}=R h a, R^{3}=O H$

16. $(2 R, 3 R)$-Dihydroquercetin-7-O- $\alpha$-L-rhamnoside, $R^{1}=H R^{2}=R h a, R^{3}=O H$

17. (2R, 3R)-Dihydroquercetin, $\mathrm{R}^{1}=\mathrm{R}^{2}=\mathrm{H}, \mathrm{R}^{3}=\mathrm{OH}$

18. 2, 3-Trans-dihydro-3, 5, 4'-trihydroxyflavonol-7-O- $\alpha$-L-rhamnoside, $\mathrm{R}^{1}=\mathrm{R}^{3}=\mathrm{H}, \mathrm{R}^{2}=\mathrm{Rha}$

\subsection{Phloroglucinols}

Phloroglucinol derivatives were the other main components of $H$. japonicum. Eleven compounds, including japonicins A-D (20-23), sarothralens A-D (24-27), saroaspidin A (28), sarothralin G (29) and sarothralin (30) were isolated from this species two decades ago. After that, only one new phloroglucinol named 4,6-dimethyl-1-O-[ $\alpha$-L-rhamnosyl $(1 \rightarrow 6)-\beta$-D-glucosyl] multifidol (31) was obtained from this species (Figure 2).

Figure 2. Chemical structures of phloroglucinols 20-31 from H. japonicum.<smiles>CC(C)OC1=C(O)C(C)(C)C(O)=C(CC2=C(O)C(C)(C)C(OC(C)C)=C(O)C2=O)C1=O</smiles>

20. Japonicin A<smiles>CC(C)=CCOc1cc(O)c(CC2=C(O)C(C)(C)C(O)=C(C(=O)C(C)C)C2=O)c(O)c1C(=O)c1ccccc1</smiles>

22. Japonicin C<smiles>CC(C)=CCCC1(C)C=Cc2c(O)c(CC3=C(O)C(C)(C)C(O)=C(C(=O)C(C)C)C3=O)c(O)c(C(=O)C(C)C)c2O1</smiles>

21. Japonicin B<smiles>CC(C)C(=O)C1=C(O)C(C)(C)C=C(Cc2cc(C(=O)C(C)C)c(O)c(CC3=C(O)C(C)(C)C(O)=C(C(=O)C(C)C)C3=O)c2O)C1=O</smiles>

23. Japonicin D 
Figure 2. Cont.<smiles>CC(C)=CCC/C(C)=C/Cc1c(O)c(CC2=CC(C)(C)C(O)=C(C(=O)C(C)C)C2=O)c(O)c(C(=O)C(C)C)c1O</smiles>

24. Sarothralen A<smiles>CC(C)=CCCC1(C)C=Cc2c(O)c(CC3=C(O)C(C)(C)C(O)=C(C(=O)C(C)C)C3=O)c(O)c(C(=O)C(C)C)c2O1</smiles>

25. Sarothralen B<smiles>CC(C)=CCCC1(C)Oc2c(c(O)c(CC3=C(O)C(C)(C)C(O)=C(C(=O)C(C)C)C3=O)c(O)c2C(=O)C(C)C)CC1O</smiles>

26. Sarothralen C<smiles>CC(C)=CCCC1(C)Oc2c(c(O)c(C(=O)C(C)C)c(O)c2C2=C(O)C(C)(C)C(O)=C(C(=O)C(C)C)C2=O)CC1O</smiles>

27. Sarothralen D<smiles>Cc1c(O)c(CC2=C(O)C(C)(C)C(O)=C(C(=O)C(C)C)C2=O)c(O)c(C(=O)C(C)C)c1O</smiles>

28. Saroaspidin A 
Figure 2. Cont.<smiles>CC(C)=CCC/C(C)=C/Cc1c(O)c(CC2=C(O)C(C)(C)C(O)=C(C(=O)C(C)C)C2=O)c(O)c(-c2ccccc2)c1O</smiles>

29. Sarothralin G<smiles>CC(C)=CCOc1cc(O)c(CC2=C(O)C(C)(C)C(O)=C(C(=O)C(C)C)C2=O)c(O)c1C(=O)C(C)C</smiles>

30. Sarothralin<smiles>CCC(C)C(=O)c1c(O)c(C)c(O)c(C)c1O</smiles>

31.4,6-Dimethyl-1-O-[ $\alpha$-L-rhamnosyl( $1 \rightarrow 6)-\beta$-D-glucosyl] multifidol, $\mathrm{R}=\mathrm{Rha}(1 \rightarrow 6) \mathrm{Glc}$

\subsection{Xanthones}

The xanthone derivatives, 1,5,6-trihydroxyxanthone (32), 1,3,5,6-tetrahydroxy-4-prenylxanthone (33), 1,5-dihydroxyxanthone-6-O- $\beta$-D-glucoside (34), 1,3,5,6-tetrahydroxyxanthonin (35), 1,3,6,7-tetrahydroxyxanthonin (36), 1,3,5-trihydroxyxanthone (37), isojacareubin (38), deoxyisojacareubin (39), 4',5'dihydro-1,5,6-trihydroxy-4',4',5'-trimethylfurano(2',3':4,5) xanthone (40) and bijaponicaxanthone (41) have been isolated and identified (Figure 3).

Figure 3. Chemical structures of xanthones (32-41) from H. japonicum.<smiles>O=c1c2ccc(O)c(O)c2oc2cccc(O)c12</smiles>

32. 1,5,6-Trihydroxyxanthone<smiles>CC(C)=CCCc1c(O)cc(O)c2c(=O)c3ccc(O)c(O)c3oc12</smiles>

33. 1,3,5,6-Tetrahydroxy-4-prenylxanthone 
Figure 3. Cont.<smiles>COc1ccc2c(=O)c3c(O)cccc3oc2c1O</smiles>

34. 1,5-Dihydroxyxanthone-6-O- $\beta$-D-glucoside<smiles>[R]c1ccc2c(=O)c3c(O)cc4c(c3oc2c1O)C=CC(C)(C)O4</smiles>

38. Isojacareubin, $\mathrm{R}=\mathrm{OH}$

39. Deoxyisojacareubin, $\mathrm{R}=\mathrm{H}$<smiles>[R]c1cc2c(=O)c3c(O)cc(O)cc3oc2c([R])c1[R]</smiles>

35. $1,3,5,6$-Tetrahydroxyxanthonin, $\mathrm{R}^{1}=\mathrm{R}^{2}=\mathrm{OH}, \mathrm{R}^{3}=\mathrm{H}$

36. 1,3,6,7-Tetrahydroxyxanthonin, $\mathrm{R}^{1}=\mathrm{H}, \mathrm{R}^{2}=\mathrm{R}^{3}=\mathrm{OH}$

37. 1,3,5-Trihydroxyxanthone, $\mathrm{R}^{1}=\mathrm{OH}, \mathrm{R}^{2}=\mathrm{R}^{3}=\mathrm{H}$<smiles>CC1c2c(cc(O)c3c(=O)c4ccc(O)c(O)c4oc23)OC1(C)C</smiles>

40. 4',5'-Dihydro-1,5,6-trihydroxy-4',4',5'trimethylfurano $\left(2^{\prime} 3^{\prime}: 4,5\right)$ xanthone<smiles></smiles>

41. Bijaponicaxanthone

\subsection{Other Compounds}

Three chromones 42-44, three triterpenes 45-47, three phenolic acids 48-50, three phenols 51-53, a ketone 54, an alcohol 55 and a sterol 56 have been obtained during the phytochemical studies (Figure 4). 
Figure 4. Chemical structures of other compounds (42-56) from H. japonicum.<smiles>[R]CC(C)c1cc(=O)c2c(O)cc(O)c(O[Cl+])c2o1</smiles>

42. 5,7-Dihydroxy-2-isopropyl-chromone-8- $\beta$-D-glucoside, $\mathrm{R}=\mathrm{H}$

43. 5,7-Dihydroxy-2-(1-methylpropyl) chromone-8- $\beta$-D-glucoside, $\mathrm{R}=\mathrm{CH}_{3}$

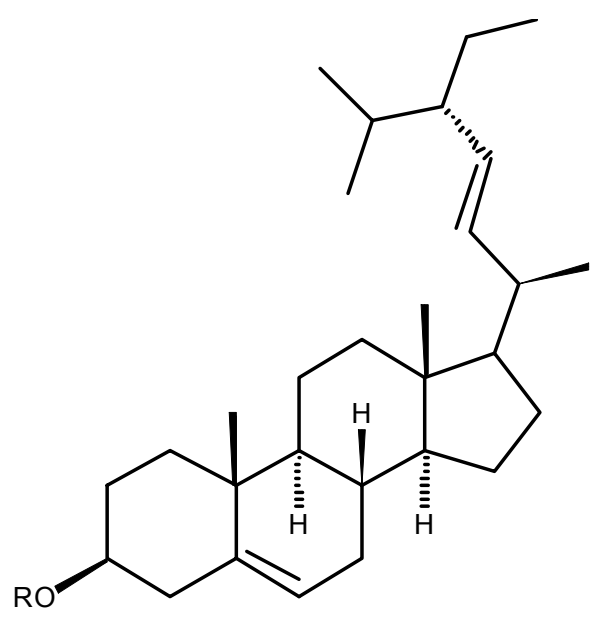

45. Stigmasterol, $\mathrm{R}=\mathrm{H}$

46. Stigmasterol-3-O- $\beta$-D-glucoside, $\mathrm{R}=\mathrm{Glc}$<smiles>O=C(/C=C/c1ccc(O)c(O)c1)OC1C[C@@](O)(C(=O)O)C[C@H](O)[C@H]1O</smiles>

48. Chlorogenic acid<smiles>O=C(O)c1ccc(O)c(O)c1</smiles>

50. 3,4-Dihydroxybenzoic acid<smiles>CC1(C)C=Cc2c(cc(O)c3c2oc(=O)c2c(O)cccc23)O1</smiles>

44. Sarolactone

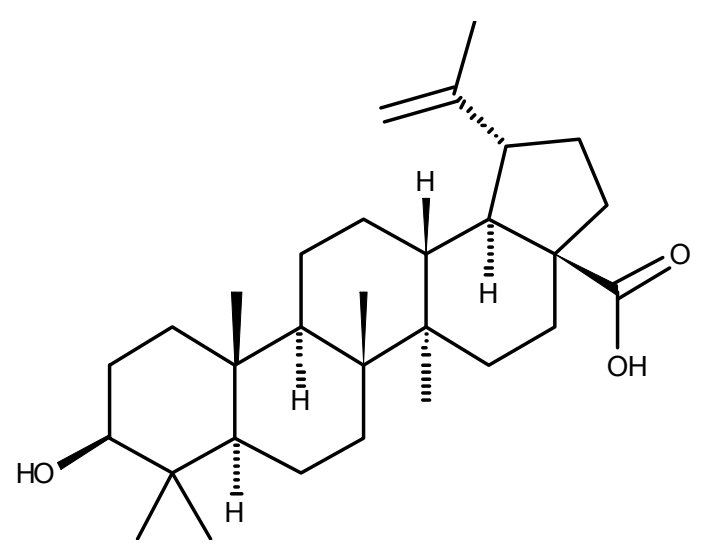

47. Betulinic acid

49. Vanillic acid<smiles>CCCOC(=O)/C=C/c1ccc(O)c(O)c1</smiles>

51. Octadecyl caffeate 
Figure 4. Cont.<smiles>CCC(C)C(=O)c1c(O)c(C)c(OCC=C(C)CCC=C(C)C)c(C(C)=O)c1O</smiles>

52. 2-Acetyl-3,5-dihydroxy-1-geranoxy-6-methyl-4-(2-methyl)butyryl-benzene<smiles>Oc1cc(O)c2c(c1)OC(c1ccc(O)c(O)c1)C(O)C2</smiles>

53. (-)-Epicatechin<smiles>CC(C)=CCC/C(C)=C/CCC(C)(O)C1CC=C(C)CC1</smiles>

55. 9-Geranyl- $\alpha$-terpineol<smiles>CC(C)C(=O)C1C(=O)C(C)(C)C(=O)C(C)(C)C1=O</smiles>

54. Flavesone<smiles>CC[C@H](CC[C@@H](C)[C@H]1CC[C@H]2C3CC=C4CC(O)CC[C@]4(C)[C@H]3CC[C@@]21C)C(C)C</smiles>

56. $\beta$-Sitosterol

Table 2. The main volatile components of $H$. japonicum.

\begin{tabular}{cccc}
\hline \multicolumn{2}{c}{ Roots } & \multicolumn{2}{c}{ Aerial Parts } \\
\hline Compound & Relative Percentage & Compound & Relative Percentage \\
\hline Dodecyl acetate & $20.59 \%$ & Undecane & $19.25 \%$ \\
Decyl dichlorocetate & $13.09 \%$ & Dodecyl acetate & $16.86 \%$ \\
3-Methyl oxirane-2- & $9.37 \%$ & $(E)-\beta$-Farnesene & $10.84 \%$ \\
methanol & $8.41 \%$ & $\beta$-Curcumin & $10.32 \%$ \\
Capraldehyde & $8.13 \%$ & Tetradecanol & $6.54 \%$ \\
$\beta$-Caryophyllene & $5.74 \%$ & 2,6-Bimethyl-6-(4-methyl-3- & $6.15 \%$ \\
$(E)-\beta$-Farnesene & $5.18 \%$ & pentenyl)bicyclo[3.1.1]hept-2-ene & \\
Nonane & &
\end{tabular}




\subsection{Volatile Oil}

The volatile oil extracted from the roots and the aerial parts (stems and leaves) of H. japonicum were analyzed by GC-MS, and thirty-two and forty-three constituents were identified, respectively. As the results show, there was obvious chemical variability in the volatile oil composition: the contents of six chemotyppes including hydrocarbons, alcohols (phenols), aldehydes/ketones, acids, esters and amines were $31.92 \%, 11.47 \%, 9.95 \%, 0.56 \%, 40.03 \%$ and $4.13 \%$ in the roots, respectively, and $62.16 \%, 8.12 \%, 2.72 \%, 1.24 \%, 18.96 \%$ and $5.75 \%$ in the aerial parts, respectively [25]. The main volatile components that represented more than $5 \%$ of the total volatile oils are summarized in Table 2 .

\subsection{Metallic Elements}

Fifteen rare earth elements in wild $H$. japonicum materials were analyzed by inductively coupled plasma mass spectrometry (ICP-MS). The results showed that the concentrations of $\mathrm{La}, \mathrm{Ce}, \mathrm{Pr}, \mathrm{Nd}$, $\mathrm{Sm}, \mathrm{Eu}, \mathrm{Gd}, \mathrm{Tb}, \mathrm{Dy}, \mathrm{Ho}, \mathrm{Er}, \mathrm{Yb}, \mathrm{Tm}, \mathrm{Lu}$ and $\mathrm{Y}$ ranged from 6 to $14522 \mathrm{ng} / \mathrm{g}$, and among them the concentrations of $\mathrm{La}, \mathrm{Ce}$ and $\mathrm{Nd}$ were higher than 2,000 $\mathrm{ng} / \mathrm{g}$ [26]. In addition, the contents of other five metallic elements, $\mathrm{Zn}, \mathrm{Cu}, \mathrm{Pb}, \mathrm{Cr}$ and $\mathrm{Cd}$ were measured by flame atomic absorption spectrophotmetry (FAAS) [27].

\section{Pharmacology}

\subsection{Antioxidant Activity}

The antioxidant effect of $H$. japonicum is one of the most prominent effects due to its responsibility for many of the other activities. The aqueous extracts of $H$. japonicum have been demonstrated to have obvious antioxidant activity by molybdenum reduction, DPPH scavenging, $\beta$-carotene bleaching inhibition and lipid peroxidation inhibition methods with values of $37.28 \pm 0.54 \mu \mathrm{g} / \mathrm{mg}$, $\mathrm{IC}_{50}=77.7 \pm 5.6 \mu \mathrm{g}, 83.18 \%$ and $95.38 \%$, respectively. By reducing the generation of hydroxyl radicals, the aqueous extract effectively reduced the oxidative damage of the DNA [28].

Quercetin-7-O- $\alpha$-L-rhamnoside is one of main flavonoids in $H$. japonicum. Oral treatment with quercetin-7-O- $\alpha$-L-rhamnoside $(0.5,1.0$ and $2.0 \mathrm{mg} / \mathrm{kg})$ in bile duct ligation-injured liver fibrosis rats showed increases of superoxide dismutase (SOD) and glutathione peroxidase (GSH-Px) level, and a decrease of malondialdehyde (MDA) content in liver. In vitro, inhibiting the overexpression of ROS and GSH depletion is a very important reason for quercetin-7-O- $\alpha$-L-rhamnoside to attenuate L-02 cell injury induced by glycochenodeoxycholic acid [29].

\subsection{Hepatoprotective Activity}

Total bilirubin (TBIL), alanine transaminase (ALT) and aspartate transaminase (AST) in serum are three markers for liver function. After intraperitoneal administration with ethanol and ethyl acetate extract of $H$. japonicum $(0.2,0.6$ and $1.8 \mathrm{~g}$ raw materials $/ \mathrm{kg})$ to rats with acute liver injury induced by D-aminogalactose, the levels of ALT and AST in all treatment groups were reduced remarkably when compared to those in the model group [30]. The aqueous extract (4.5 g raw material $/ \mathrm{kg}$ ) exhibited an obvious effect by decreasing AST, ALT and TBIL levels in serum of mice with liver injury induced by 
$\mathrm{CCl}_{4}$, indicating its hepatoprotective effects [31]. When three flavonoids isolated from $H$. japonicum, namely quercitrin, isoquercitrin and quercetin-7-O- $\alpha$-L-rhamnoside $(0.25,0.5$ and $1.0 \mathrm{mg} / \mathrm{kg})$, were used separately to treat the liver injury in rats induced by $\mathrm{CCl}_{4}$ and $\mathrm{D}$-aminogalactose, the levels of AST, ALT and TBIL were significantly reduced at the three dose levels as compared to the model group [32]. Furthermore, intraperitoneal treatment with quercetin-7-O- $\alpha$-L-rhamnoside $(0.25,0.5$ and $1.0 \mathrm{mg} / \mathrm{kg}$ ) of rats with liver fibrosis induced by bile duct ligation showed a reduction in levels of type III procollagen, hyaluronic acid, laminin and TNF- $\alpha$ in serum and expression of smooth muscle actin- $\alpha$ in liver [33].

\subsection{Anti-Cancerous Activity}

The anti-cancerous effect is a noticeable bioactivity for $H$. japonicum reported in the last decade. H. japonicum extract significantly inhibited the proliferation of human tongue cancer cell line TSCCa in vitro in a dose-dependent manner by damaging the mitochondria and rough endoplasmic reticulum [34]. The extract of $H$. japonicum significantly inhibited the proliferation of CNE-2 cells and HepG2 cells in vitro by inducing cell cycle arrest, showing a dose-dependent response at the low concentrations of $25 \mathrm{mg} / \mathrm{mL}$ and $5 \mathrm{mg} / \mathrm{mL}$, respectively [35-37]. Meanwhile, the aqueous extract of $H$. japonicum displayed a synergistic tumor-inhibiting effect with 5 -FU in mice at 3,6 and $12 \mathrm{~g} / \mathrm{kg} /$ day, administered $24 \mathrm{~h}$ after the tumor inoculation, once daily for 10 days, indicting its usefulness in antitumor therapy [38]. Using a serum pharmacology method, BEL-7404 liver cancer cells were co-cultured with the collected serum containing four fraction of $H$. japonicum (ethanol extract, ethyl acetate extract, $n$-butanol extract and aqueous extract) at different dosage. All extracts showed inhibitory activity on the growth of BEL-7404 cell with inhibitory rates of $29.74 \%, 53.80 \%, 40.79 \%$ and $54.24 \%$, respectively [39].

\subsection{Antibacterial Activity}

Antibacterial activity for aqueous extract of $H$. japonicum was studied by the disc diffusion method. The results demonstrated that both Gram positive and Gram negative bacteria, including Escherichia coli, Alcaligens faecalis, Bacillus subtilis, E. aerogenes, Klebsiella pneumonia, Shigella flexneri, Salmonella enterica ser. Typhi, Staphylococcus aureus, Staphylococcus epidermidis, Streptococcus pyogenes, Xanthomonas vesicatoria, $X$. oryzae pv. oryzae and $X$. malvacearum were inhibited by the extract, except for $P$. aeruginosa, and the minimum inhibitory concentration (MICs) of the extract was $1 \mathrm{mg} / \mathrm{mL}$ against all the test cultures used, except E. aerogenes and $P$. aeruginosa. This indicated the extract had a broad spectrum antibacterial activity [28].

Isojacareubin, the xanthone from the aerial parts of $H$. japonicum had an effect on methicillin-resistant Staphylococcus aureus (MRSA) with MICs/MBCs ranging from $4 / 16$ to $16 / 64 \mu \mathrm{g} / \mathrm{mL}$. When it was used together with some conventional antibacterial agents, namely ceftazidime, levofloxacin and ampicillin, the values of $50 \%$ of the fractional inhibitory concentration indices $\left(\mathrm{FICI}_{50}\right)$ were $0.25,0.37$ and 0.37 , respectively, indicating good anti-MRSA activities [40]. 


\subsection{Antiviral Activity}

Using a serum pharmacology method, the anti-HBV effect for different extracts (ethanol extract, ethyl acetate extract, $n$-butanol extract and aqueous extract) of $H$. japonicum were tested in vitro. The aqueous extract showed better anti-HBV activity than the other three extracts with inhibitory rates on HBeAg and HBsAg of $70 \%$ and $30 \%$, respectively [39]. In an in vivo study, H. japonicum extract showed strong activity against duck hepatitis B virus at dosage of $6.5,13.0$ and $26.0 \mathrm{mg} / \mathrm{kg}$, once a day, for 28 days [41]. In addition, the 75\% ethanol extract of $H$. japonicum exhibited anti-influenza virus $\mathrm{H} 3 \mathrm{~N} 2$ effect in vivo after $10 \mathrm{~g} / \mathrm{kg}$ oral administration in mice infected with the H3N2 virus [42].

\subsection{Effects on Cardiovascular System}

The bioactive compound quercetin-7-O- $\alpha$-L-rhamnoside isolated from $H$. japonicum was tested for its coagulant activity via an in vitro experiment. This flavonol glycoside $\left(10^{-5} \mathrm{~g} / \mathrm{L}\right)$ exhibited excellent effects on promoting the coagulation of activated partial thromboplastin time and prothrombin time in dose-dependent manner [7]. Oral administration of the aqueous extract of $H$. japonicum (11.25 $\mathrm{g}$ raw material $/ \mathrm{kg} /$ day) in hyperlipidemic rats for 8 weeks, significantly reduced the serum levels of triglycerides, total cholesterol, low density lipoprotein cholesterol and atherosclerotic index, but increased the level of high density lipoprotein cholesterol. Meanwhile, the hematocrit, blood and plasma viscosity were markedly decreased in this study, indicating the aqueous extract of $H$. japonicum had an adjustment effect on hemorheology [43]. Furthermore, the contents of monocyte chemoattractant protein-1, lipoprotein associated phospholipase A2 and macrophage migration inhibitory factor in serum were also obviously decreased, indicating the inhibitory effect on the atherosclerosis process [44].

\subsection{Effects on Immunity}

The effect of $H$. japonicum extract on systemic immune functions was investigated by subcutaneous injection in rats with a dosage of $2 \mathrm{~g}$ raw material $/ \mathrm{kg}$, and the results showed that $H$. japonicum extract obviously increased the phagocytic rate of neutrophils $(83.5 \% \pm 5.1 \%)$ and enhanced the $\mathrm{T}$ lymphocyte ratio $(68.8 \% \pm 6.5 \%)$ in the peripheral blood of male rats [45]. In addition, the extract showed strong effects on improving the immune function, reducing the toxic effect of 5-fluorouracil and prolonging the survival time in the tumor-bearing mice. Therefore, it was considered to have immunoregulatory activity [38].

\section{Quality Control}

So far, the quality evaluation of $H$. japonicum materials has been not listed in the Chinese Pharmacopoeia (2010 edition), even though it has been used as a traditional medicine for a long time. Much effort thus is made to establish a comprehensive method for ensuring the quality of H. japonicum. For the safety and efficacy of herbal medicines, the first step in assuring quality is correct identification [46]. Traditionally morphological and microscopic approaches have been used for H. japonicum identification [3]. However, these traditional methods are very limited for Hypericum herbs or processed products with similar macroscopic and anatomical characteristics. DNA markers have now become the popular means for the identification of plants because genetic composition is 
effective and unique for each individual and is less affected by age, physiological condition, environmental factors, harvest time, storage and processing conditions [47]. Internal transcribed spacer sequence (ITS) of nuclear ribosomal DNA (nrDNA) as a common DNA marker was applied to H. japonicum. A series of ITS sequences of $H$. japonicum from different research groups are reported in GenBank. However, there is still no literature on a molecular method developed for accurate identification of H. japonicum.

Qualitative and quantitative analysis for the quality control of $H$. japonicum has mostly focused on flavonoid components since flavonoids have been proven to be largely responsible for many of the biological activities of $H$. japonicum in pharmacological studies. Thin layer chromatography (TLC) has been applied to qualitative identification of $H$. japonicum by using the flavonoid components, isoquercitrin and quercitrin as chemical markers [48]. However, TLC quantification is thought to be relatively poor in sensitivity, resolution and reproducibility. High performance liquid chromatography (HPLC) coupled with ultraviolet spectroscopy (UV) and electrospray ionization (ESI)-mass spectrometry (MS) have become the common analytical techniques for separation and quantitation of chemical markers from complicated herbal medicine extracts. HPLC methods for the quantitation of specific chemicals in $H$. japonicum are summarized in Table 3. Isojacareubin, quercetin-7-O- $\alpha$-Lrhamnoside, quercetin and quercitrin, each of which was recognized as characteristic and/or bioactive component, were used as individual chemical markers for quality evaluation of $H$. japonicum materials [49-53]. A lot of HPLC methods on the basis of multiple components with potential bioactivities have been developed for quantitation and presenting further useful information on this species. As the results show, the contents of flavonoids considered as the bioactive components in H. japonicum materials were found to vary [8,54-61]. Various reasons, such as growth environment, growth periods, harvesting season, processing method, storage condition and period might cause variation in the chemical compositions of the various samples $[8,56,58-60]$.

Chemical fingerprints could show the complicated components of herbal medicines, not only the naturally occurring bioactive and characteristic components, but also their relative ratios [62]. Chemical fingerprint analysis which is recognized as a reliable means for the identification and qualification of herbal medicines, has been accepted by Food and Drug Administration (2000) [63], European Medicines Agency (2001) [64], and State Food and Drug Administration of China (2000) [65] and other authorities as a strategy for quality assessment of herbal medicines. A HPLC-diode array detector (DAD) fingerprint was applied to 56 batches of $H$. japonicum materials from six provinces in China. The results showed that the most relevant factor in secondary metabolites of $H$. japonicum was collection location, followed by harvesting time [62]. Moreover, the on-line LC-MS ${ }^{\mathrm{n}}$ technique, which provides a ready method for elucidation of compounds and more information in the fingerprint by reprocessing the mass spectrometry data using tandem MS, has become a powerful means in the quality control and quantitative analysis of complicated medicinal herbs. A HPLC-PAD-ESI-MS ${ }^{n}$ method was successfully developed to evaluate the quality of $H$. japomicum from different origins by establishing chromatographic fingerprints, in which 20 common peaks of 10 batches of $H$. japomicum were identified [58]. Headspsce GC-MS (HSGC-MS) was used to establish the fingerprint of the volatile components from 11 batches of $H$. japonicum materials. The HSGC-MS fingerprint with 12 common peaks was characteristic and useful for quality control of $H$. japonicum materials [66]. Additionally, a high performance capillary electrophoresis (HPCE) fingerprint based on six main peaks was also established for quality control of H. japonicum materials [67]. 
Table 3. HPLC applications on quantitative analysis for quality control of $H$. japonicum.

\begin{tabular}{|c|c|c|c|c|c|c|}
\hline Analytes & Extraction Methods & Columns & Mobile Phase & $\begin{array}{c}\text { Analytical } \\
\text { Time }\end{array}$ & Detections & References \\
\hline Isojacareubin & $\begin{array}{l}\text { Refluxing extraction with } 75 \% \\
\text { (v/v) methanol aqueous solution }\end{array}$ & $\begin{array}{l}\text { C18 (Diamonsil, } 4.6 \mathrm{~mm} \times \\
200 \mathrm{~mm}, 5 \mu \mathrm{m})\end{array}$ & $\begin{array}{l}\text { Acetonitrile-methanol-water-phosphoric } \\
\text { acid (45:15:50:0.05); flow rate: } 1.0 \mathrm{~mL} / \mathrm{min}\end{array}$ & $40 \min$ & UV $254 \mathrm{~nm}$ & [49] \\
\hline Isojacareubin & $\begin{array}{l}\text { Ultrasonic extraction with } 80 \% \\
\text { (v/v) ethanol aqueous solution }\end{array}$ & $\begin{array}{l}\text { C18 (Hypersil, } 4.6 \mathrm{~mm} \times \\
250 \mathrm{~mm}, 5 \mu \mathrm{m})\end{array}$ & $\begin{array}{l}\text { Acetonitrile- } 0.04 \% \text { phosphoric acid } \\
\text { (47:53); flow rate: } 1.0 \mathrm{~mL} / \mathrm{min}\end{array}$ & $28 \mathrm{~min}$ & UV $254 \mathrm{~nm}$ & [50] \\
\hline $\begin{array}{l}\text { Quercetin-7-O- } \alpha \text {-L- } \\
\text { rhamnoside }\end{array}$ & $\begin{array}{l}\text { Refluxing extraction with } 60 \% \\
\text { (v/v) ethanol aqueous solution }\end{array}$ & $\begin{array}{l}\text { C18 (Hypersil, } 4.6 \mathrm{~mm} \times \\
250 \mathrm{~mm}, 5 \mu \mathrm{m})\end{array}$ & $\begin{array}{l}\text { Acetonitrile- } 0.04 \% \text { phosphoric acid } \\
\text { (77:23); flow rate: } 1.0 \mathrm{~mL} / \mathrm{min}\end{array}$ & $20 \mathrm{~min}$ & UV $371 \mathrm{~nm}$ & [51] \\
\hline Quercetin & $\begin{array}{l}\text { Refluxing extraction with } \\
\text { methanol and } 25 \% \text { hydrochloric } \\
\text { acid aqueous solution }(3: 1)\end{array}$ & $\begin{array}{l}\text { C18 (Diamonsil, } 4.6 \mathrm{~mm} \times \\
250 \mathrm{~mm}, 5 \mu \mathrm{m} \text { ) }\end{array}$ & $\begin{array}{l}\text { Methanol- } 0.06 \% \text { phosphoric acid ( } 52: 48) \text {; } \\
\text { flow rate: } 1.0 \mathrm{~mL} / \mathrm{min}\end{array}$ & $20 \mathrm{~min}$ & UV $360 \mathrm{~nm}$ & {$[52]$} \\
\hline Quercitrin & $\begin{array}{l}\text { Ultrasonic extraction with } \\
\text { ethanol }\end{array}$ & $\begin{array}{l}\text { C18 (Agilent, } 4.6 \mathrm{~mm} \times \\
250 \mathrm{~mm}, 5 \mu \mathrm{m})\end{array}$ & $\begin{array}{c}\text { Acetonitrile- } 0.05 \mathrm{~mol} / \mathrm{L} \text { potassium } \\
\text { dihydrogenphosphate (19:81); flow rate: } \\
1.0 \mathrm{~mL} / \mathrm{min}\end{array}$ & $40 \mathrm{~min}$ & UV $256 \mathrm{~nm}$ & [53] \\
\hline $\begin{array}{l}\text { Quercetin, quercitrin and } \\
\text { isoquercitrin }\end{array}$ & $\begin{array}{l}\text { Ultrasonic extraction with } \\
80 \%(\mathrm{v} / \mathrm{v}) \text { methanol aqueous } \\
\text { solution }\end{array}$ & $\begin{array}{l}\text { C18 (Hypersil, } 4.6 \mathrm{~mm} \times \\
250 \mathrm{~mm}, 5 \mu \mathrm{m})\end{array}$ & $\begin{array}{l}\text { Acetonitrile-0.02 mol/L potassium } \\
\text { dihydrogenphosphate }(14: 86) \text { with } \\
\text { gradient elution; flow rate: } 1.0 \mathrm{~mL} / \mathrm{min}\end{array}$ & $45 \mathrm{~min}$ & UV $360 \mathrm{~nm}$ & [54] \\
\hline $\begin{array}{l}\text { Quercetin, rutin and } \\
\text { isorhamnetin }\end{array}$ & $\begin{array}{c}\text { Soxhlet extraction with } \\
\text { methanol }\end{array}$ & $\begin{array}{l}\text { BDS-C18 (Agilent, } 4.6 \mathrm{~mm} \times \\
250 \mathrm{~mm}, 5 \mu \mathrm{m})\end{array}$ & $\begin{array}{l}\text { Methanol- } 0.2 \% \text { phosphoric acid }(52: 48) \\
\text { flow rate: } 1.0 \mathrm{~mL} / \mathrm{min}\end{array}$ & $16 \mathrm{~min}$ & UV $260 \mathrm{~nm}$ & [8] \\
\hline $\begin{array}{l}\text { Quercetin, rutin and } \\
\text { isorhamnetin }\end{array}$ & $\begin{array}{l}\text { Ultrasonic extraction with } \\
60 \%(\mathrm{v} / \mathrm{v}) \text { ethanol aqueous } \\
\text { solution }\end{array}$ & $\begin{array}{l}\text { C18 (Agilent, } 4.6 \mathrm{~mm} \times \\
\quad 250 \mathrm{~mm}, 5 \mu \mathrm{m})\end{array}$ & $\begin{array}{c}\text { Methanol- } 0.2 \% \text { phosphoric acid }(54: 46) \\
\text { flow rate: } 1.0 \mathrm{~mL} / \mathrm{min}\end{array}$ & $15 \mathrm{~min}$ & UV $261 \mathrm{~nm}$ & [55] \\
\hline
\end{tabular}


Table 3. Cont.

\begin{tabular}{|c|c|c|c|c|c|c|}
\hline Analytes & Extraction Methods & Columns & Mobile Phase & $\begin{array}{c}\text { Analytical } \\
\text { Time }\end{array}$ & Detections & References \\
\hline $\begin{array}{l}\text { Quercetin, quercitrin, isoquercitrin } \\
\text { and quercetin-7-O- } \alpha \text {-L-rhamnoside }\end{array}$ & $\begin{array}{l}\text { Refluxing extraction with } \\
60 \%(\mathrm{v} / \mathrm{v}) \text { ethanol aqueous } \\
\text { solution }\end{array}$ & $\begin{array}{l}\text { SB-C18 (Agilent } \\
\text { ZORBAX, } 4.6 \mathrm{~mm} \times \\
250 \mathrm{~mm}, 5 \mu \mathrm{m})\end{array}$ & $\begin{array}{c}\text { Acetonitrile- } 0.5 \% \text { acetic acid }(12: 88) \\
\text { with gradient elution; } \\
\text { flow rate: } 1.0 \mathrm{~mL} / \mathrm{min}\end{array}$ & $45 \mathrm{~min}$ & UV $360 \mathrm{~nm}$ & {$[56]$} \\
\hline $\begin{array}{l}\text { Quercetin, quercitrin, isoquercitrin } \\
\text { and quercetin-7-O- } \alpha \text {-L-rhamnoside }\end{array}$ & $\begin{array}{c}\text { Refluxing extraction with } \\
\text { water }\end{array}$ & $\begin{array}{l}\text { HC C18 (Agilent, } 4.0 \mathrm{~mm} \\
\quad \times 250 \mathrm{~mm}, 5 \mu \mathrm{m})\end{array}$ & $\begin{array}{c}\text { Methanol-2.5\% acetic acid }(36: 64) \\
\text { flow rate: } 1.0 \mathrm{~mL} / \mathrm{min}\end{array}$ & $50 \mathrm{~min}$ & UV $255 \mathrm{~nm}$ & {$[57]$} \\
\hline $\begin{array}{l}\text { Quercetin, quercitrin, isoquercitrin, } \\
\text { taxifolin-7-O- } \alpha-\mathrm{L}-\text { rhamnoside and } \\
\text { kaempferol }\end{array}$ & $\begin{array}{l}\text { Ultrasonic extraction with } \\
50 \%(\mathrm{v} / \mathrm{v}) \text { methanol aqueous } \\
\text { solution }\end{array}$ & $\begin{array}{l}\text { C18 (Luna, } 4.6 \mathrm{~mm} \times \\
250 \mathrm{~mm}, 5 \mu \mathrm{m})\end{array}$ & $\begin{array}{c}\text { Methanol- } 0.5 \% \text { acetic acid }(54: 46) \\
\text { flow rate: } 1.0 \mathrm{~mL} / \mathrm{min}\end{array}$ & $50 \mathrm{~min}$ & UV $350 \mathrm{~nm}$ & {$[58]$} \\
\hline $\begin{array}{l}\text { Quercetin, quercitrin, isoquercitrin, } \\
\text { quercetin-7-O- } \alpha \text {-L-rhamnoside and } \\
\text { taxfolin-7-O- } \alpha \text {-L-rhamnoside }\end{array}$ & $\begin{array}{l}\text { Ultrasonic extraction with } \\
70 \%(\mathrm{v} / \mathrm{v}) \text { methanol aqueous } \\
\text { solution }\end{array}$ & $\begin{array}{l}\text { SB-C18 (Agilent } \\
\text { ZORBAX, } 4.6 \mathrm{~mm} \times \\
250 \mathrm{~mm}, 5 \mu \mathrm{m})\end{array}$ & $\begin{array}{l}\text { Acetonitrile- } 0.5 \% \text { formic acid } \\
\text { (12:88) with gradient elution; } \\
\quad \text { flow rate: } 1.0 \mathrm{~mL} / \mathrm{min}\end{array}$ & $70 \mathrm{~min}$ & $\begin{array}{l}\text { UV } 256 \mathrm{~nm} \\
\text { and MS }\end{array}$ & [59] \\
\hline $\begin{array}{l}\text { Quercetin, quercitrin, isoquercitrin, } \\
\text { rutin, kaempferol and quercetin-3-O- } \\
\text { galactoside }\end{array}$ & $\begin{array}{l}\text { Refluxing extraction with } \\
80 \%(\mathrm{v} / \mathrm{v}) \text { methanol aqueous } \\
\text { solution }\end{array}$ & $\begin{array}{l}\text { C18 (Alltima, } 4.6 \mathrm{~mm} \times \\
250 \mathrm{~mm}, 5 \mu \mathrm{m})\end{array}$ & $\begin{array}{l}\text { Acetonitrile- } 0.8 \% \text { acetic acid }(11: 89) \\
\text { with gradient elution; } \\
\text { flow rate: } 0.8 \mathrm{~mL} / \mathrm{min}\end{array}$ & $70 \mathrm{~min}$ & $\begin{array}{l}\text { UV } 254 \mathrm{~nm} \\
\text { and MS }\end{array}$ & {$[60]$} \\
\hline $\begin{array}{l}\text { Quercetin, quercitrin, isoquercitrin, } \\
\text { quercetin-7-O- } \alpha \text {-rhamnoside, } 3,4- \\
\text { dihydroxybenzoic acid, taxifolin-7-O- } \\
\alpha \text {-L-rhamnoside, } 5,7-\text { dihydroxy-2- } \\
\text { isopropyl and chormone-8- } \beta \text {-D- } \\
\text { glucoside }\end{array}$ & $\begin{array}{l}\text { Ultrasonic extraction with } \\
70 \%(\mathrm{v} / \mathrm{v}) \text { methanol aqueous } \\
\text { solution }\end{array}$ & $\begin{array}{l}\text { XB-C18 (Ultimate, } 4.6 \mathrm{~mm} \\
\quad \times 250 \mathrm{~mm}, 5 \mu \mathrm{m})\end{array}$ & $\begin{array}{l}\text { Methanol-water }(5: 95) \text { with } \\
\text { gradient elution; } \\
\text { flow rate: } 1.0 \mathrm{~mL} / \mathrm{min}\end{array}$ & $100 \mathrm{~min}$ & $\begin{array}{l}\text { UV } 254 \mathrm{~nm} \\
\text { and } \mathrm{MS}\end{array}$ & [61] \\
\hline
\end{tabular}




\section{Pharmacokinetics}

A HPLC-DAD method was established and applied successfully to the pharmacokinetic study of quercitrin and isoquercitrin in rat plasma after oral administration of $80 \%$ ethanol extract of $\mathrm{H}$. japonicum at a dose of $23.0 \mathrm{~g} / \mathrm{kg}$, equivalent to 48.3 and $62.1 \mathrm{mg} / \mathrm{kg}$ of quercitrin and isoquercitrin, respectively. The pharmacokinetic results suggested that the maximum concentrations of quercitrin and isoquercitrin occured after approximately 1.30 and $1.17 \mathrm{~h}$, respectively. Quercitrin and isoquercitrin were still detectable in rat plasma for at least $24 \mathrm{~h}$ after oral administration of the extract. These findings provided useful evidence for evaluating the clinical efficacy of H. japonicum [68].

\section{Conclusions}

Pharmacological studies on flavonoids have been performed in vitro and in vivo in animals, while the pharmacological studies on other main bioactive components such as phloroglucinols and xanthones are rare. Though several pharmacological mechanisms related to biological activity have already been explained, the comprehensive pharmacological mechanisms of $H$. japonicum need to be elucidated. Based on phytochemical and pharmacological research, the flavonoids responsible for the good hepatoprotective, anti-tumor and antibacterial activities were selected as chemical markers to evaluate the quality of $H$. japonicum and its products. Meanwhile, various methods have been successfully applied to the simultaneous analysis of the bioactive compounds in H. japonicum. However, pharmacokinetics studies on the main components, especially the bioactive components are still largely lacking, therefore firm evidence for further clinical application is necessary in order to assess the therapeutic potential of $H$. japonicum and its pharmaceutical commodities.

\section{Acknowledgments}

We thank Miss Qian-Yi Guan for valuable comments and checking the spelling and grammar mistakes in this review.

\section{Author Contributions}

Lin-Sheng Liu: Wrote the Introduction and Phytochemistry sections and sorted out the references; Meng-Hua Liu: Wrote the Pharmacology and Pharmacokinetics sections; Jing-Yu He: Contributed to design of this review, drew the structural formulas and wrote the Quality Control and Conclusions sections.

\section{Conflicts of Interest}

The authors declare no conflict of interest.

\section{References}

1. Robson, N.K.B. Hypericum botany. In Hypericum: The Genus Hypericum; Emst, E., Ed.; Taylor and Francis: New York, NY, USA, 2003; pp. 1-22.

2. Editorial board of Flora of China; The Chinese Academy of Sciences. Flora of China, 2nd ed.; Science Press: Beijing, China, 1990; Volume 50, p. 47. 
3. Guangdong Food and Drug Administration. Guangdong Food Standardization of Chinese Medicinal Materials; Guangdong Chemical Industry Press: Guangdong, China, 2004; pp. 73-75.

4. Nanjing University of Chinese Medicine. Dictionary of Chinese Traditional Medicine (Zhong. Yao Da. Ci. Dian), 2nd ed.; Shanghai Scientific \& Technical Publishers: Shanghai, China, 2006; pp. 909-911.

5. Group of Compilation of Chinese Herbal Medicine. Compilation of Chinese Herbal Medicine in China; People's Medical Publishing House: Beijing, China, 1996; p. 4.

6. Zhang, L.; Jin, Y.Y.; Tian, J.K. Studies on chemical constituents of Hypericum japonicum. Chin. Pharm. J. 2007, 42, 341-344.

7. Wu, Q.L.; Wang, S.P.; Du, L.J.; Zhang, S.M.; Yang, J.S.; Xiao, P.G. Chromone glycosides and flavonoids from Hypericum japonicum. Phytochemistry 1998, 49, 1417-1420.

8. Xi, Z.H.; Yu, J.B.; Lv, W.Q.; Li, J.; Li, C.T. Determination of flavonoids in different parts and different harvesting seasons of Hypericum japonicum. China Pharm. 2009, 20, 1635-1637.

9. Fu, P.; Li, T.Z.; Liu, R.H.; Zhang, W.; Zhang, C.; Zhang, W.D.; Chen, H.S. Studies on the flavonoids of Hypericum japonicum Thunb. ex Murray. Chin. J. Nat. Med. 2004, 2, 283-284.

10. Wu, Q.L.; Wang, S.P.; Liao, Y.H.; Wang, L.W.; Feng, Y.X.; Yang, J.S.; Xiao, P.G. New constituents from Hypericum japonicum. Chin. Chem. Lett. 1996, 7, 1011-1012.

11. Ishiguro, K.; Nagata, S.; Fukumoto, H.; Yamaki, M.; Isoi, K.; Oyama, Y. A flavanonol rhamnoside from Hypericum japonicum. Phytochemistry 1991, 30, 3152-3153.

12. Wang, X.W.; Mao, Y.; Fan, M.; Ding, A.S.; Wang, N.L.; Yao, X.S. Isolation, identification and activity determination on the anti-hypoxic components of Hypericum japonicum Thunb. J. Shenyang Pharm. Univ. 2009, 26, 701-703.

13. Gu, G.M.; Feng, S.Z.; Wang, X.Y. Antimalarial constituents of Hypericum japonicum Thunb.: Isolation and structure of japonicins A, B, C and D. Acta Chim. Sin. 1988, 46, 246-251.

14. Ishiguro, K.; Yamaki, M.; Kashihara, M.; Takagi, S. Sarothralen A and B, new antibiotic compounds from Hypericum japonicum. Planta Med. 1986, 4, 288-290.

15. Ishiguro, K.; Nagata, S.; Fukumoto, H.; Yamaki, M.; Isoi, K. Phloroglucinol derivatives from Hypericum japonicum. Phytochemistry 1994, 35, 469-471.

16. Ishiguro, K.; Yamaki, M.; Kashihara, M.; Takagi, S. Saroaspidin A, B, and C: Additional antibiotic compounds from Hypericum japonicum. Planta Med. 1987, 5, 415-417.

17. Ishiguro, K.; Yamaki, M.; Kashihara, M.; Takagi, S.; Isoi, K. Sarothralin G: A new antimicrobial compound from Hypericum japonicum. Planta Med. 1990, 56, 274-276.

18. Ishiguro, K.; Yamaki, M.; Takagi, S.; Yamagata, Y.; Tomita, K. X-ray crystal structure of sarothralin, a novel antibiotic compound from Hypericum japonicum. J. Chem. Soc. Chem. Commun. 1985, 1, 26-27.

19. Wang, X.W.; Mao, Y.; Wang, N.L.; Yao, X.S. A new phloroglucinol diglycoside derivative from Hypericum japonicum Thunb. Molecules 2008, 13, 2796-2803.

20. Fu, P.; Li, T.Z.; Liu, R.H.; Zhang, W.; Zhang, W.D.; Chen, H.S. Xanthones from the whole plant of Hypericum japonicum. Nat. Product Res. Dev. 2004, 16, 51-513.

21. Ishiguro, K.; Yamaki, M.; Kashihara, M.; Takagi, S.; Isoi, K. Studies on antimicrobial compounds from Hypericum japonicum. Part 4: A chromene from Hypericum japonicum. Phytochemistry 1990, 29, 1010-1011. 
22. Fu, P.; Zhang, W.D.; Li, T.Z.; Liu, R.H.; Zhang, W.; Chen, H.S. Study on chemical constituents of Hypericum japonicum Thunb. ex Murray. Acad. J. Sec. Mil. Med. Univ. 2004, 25, 1274-1275.

23. Lv, J.; Kong, L.Y. Studies on the constituents of Hypericum japonicum Thunb. ex Murray. Mod. Chin. Med. 2007, 9, 12-14.

24. Hu, L.H.; Khoo, C.W.; Vittal, J.J.; Sim, K.Y. Phloroglucinol derivatives from Hypericum japonicum. Phytochemistry 2000, 53, 705-709.

25. Li, X.F.; Zhang, Z.Z.; Ouyang, Y.Z.; Xu, Y.W.; Sun, Y.L. Analyses on the chemical composition of the volatile oil from the Hypericum japonicum by GC-MS. Guangdong Chem. Ind. 2013, 40, 94-95.

26. Wei, Z.L.; Rui, Y.K.; Tian, Z.H. Content of rare earth elements in wild Hypericum japonicum Thunb. Spectrosc. Spectr. Anal. 2009, 29, 1696-1697.

27. Ouyang, Y.Z.; Wei, Y.; Wu, D.H.; Sun, Y.L. Determination of heavy metal in Hypericum japonicum Thunb by microwave digestion and flame atomic absorption spectrophotmetry (FAAS). Appl. Chem. Ind. 2012, 41, 1820-1822.

28. Samaga, P.V.; Rai, V.R. Evaluation of pharmacological properties and phenolic profile of Hypericum japonicum Thunb. from Western Ghats of India. J. Pharm. Res. 2013, 7, 626-632.

29. Liang, S.; Su, W.W.; Wang, Y.G.; Peng, W.; Nie, Y.C.; Li, P.B. Effect of quercetin 7-rhamnoside on glycochenodeoxycholic acid-induced L-02 human normal liver cell apoptosis. Int. J. Mol. Med. 2013, 32, 323-330.

30. Su, J.; Fu, P.; Zhang, W.D.; Liu, R.H.; Xu, X.K.; Zhang, C. Experimental study on extracts of Hypericum japonicum in liver-protective effect. J. Pharm. Pract. 2005, 23, 342-344.

31. Wang, N.; Li, P.B.; Wang, Y.G.; Peng, W.; Wu, Z.; Tan, S.Y.; Liang, S.L.; Shen, X.; Su, W.W. Hepatoprotective effect of Hypericum japonicum extract and its fractions. J. Ethnopharmacol. 2008, 116, 1-6.

32. Li, P.B.; Wang, Y.G.; Wu, D.H.; Wu, Z.; Su, W.W. Experimental study of three flavonoids isolated from Hypericum japonicum Thunb. on hepatoprotective and jaundice-relieving effects. J. Sun Yat.-Sen. Univ. (Med. Sci.) 2007, 28, 40-43.

33. Li, P.B.; Yang, C.P.; Wang, Y.G.; Peng, W. Study on the effect of quercetin-7- $\beta$-D-rhamnosein against liver fibrosis in rats. J. Chin. Med. Mater. 2011, 34, 424-428.

34. Jin, H.X.; Li, J.R. A study of the cytotoxic effects of Hypericum japonicum Thunb on human tongue cancer cell line TSCCa in vitro. J. Clin. Stomatol. 1997, 13, 19-20.

35. Xiao, D.J.; Zhu, G.C.; Wang, X.L.; Zhang, Y.S.; Wu, S.H.; Yuan, Y. Effects of Hypericum japonicum Thunb on growth inhibition and apoptosis of human nasopharyngeal carcinoma cell line CNE-2 in vitro. Chin. J. Otorhinolaryngol.-Skull. Base Surg. 2007, 13, 337-339.

36. Xiao, D.J.; Zhu, G.C.; Wang, Y.P.; Hu, Y.L. Inhibiting effect of Hypericum japonicum Thunb on human nasopharyngeal carcinoma line CNE-2 in vitro. Mod. Oncol. 2008, 16, 15-16.

37. Lin, J.M.; Wang, R.G.; Chen, X.Z.; Zhao, J.Y. Effect of Hypericum japonicum on proliferation of human hepatoma cell line HepG2. Pharm. Clin. Chin. Mater. Med. 2007, 23, 136-137.

38. Zhang, H.B.; Lu, P.; Cao, W.B.; Zhang, Z.H.; Meng, X.L. The effect-enhancing and toxicity-reducing activity of Hypericum japonicum Thunb. extract in murine liver cancer chemotherapy. Mol. Clin. Oncol. 2013, 1, 395-399. 
39. Pan, X.J.; Yang, K.; Zeng, J.Q.; Wei, Z.Y.; Chen, C. Experimental study on anti-hepatitis B and anti-hepatoma effect of different extracts in serum of Hypericum japonicum Thunb. in vitro. Lishizhen Med. Mater. Med. Res. 2009, 20, 1076-1078.

40. Zuo, G.Y.; An, J.; Han, J.; Zhang, Y.L.; Wang, G.C.; Hao, X.Y.; Bian, Z.Q. Isojacareubin from the Chinese herb Hypericum japonicum: Potent antibacterial and synergistic effects on clinical methicillin-resistant Staphylococcus aureus (MRSA). Int. J. Mol. Sci. 2012, 13, 8210-8218.

41. Li, P.B.; Yang, C.P.; Wang, Y.G.; Peng, W. Study on the effects of the extract of Hypericum japonicum on duck hepatitis B viral. J. Chin. Med. Mater. 2011, 34, 956-958.

42. Liu, N.; Hu, X.L.; Meng, Y.R.; Zhu, Y.T.; Huang, B.S.; Lin, P.Z. Effect of anti-influenza virus H3N2 of Hypericum japonicum in vivo. J. Chin. Med. Mater. 2008, 31, 1022-1024.

43. Hu, X.Y.; Shu, X.C.; Ma, Y. Effect of aqueous extract of Hypericum japonicum on blood fat and hemorheology in restraint and hyperlipidemia rats. J. Chin. Med. Mater. 2011, 34, 1418-1420.

44. Hu, X.Y.; Ma, Y.; Li, L.L. Effect of aqueous extract of Hypericum japonicum on the progress of atherosclerosis in hyperlipidemia rats. Asia-Pac. Trad. Med. 2011, 7, 5-6.

45. Zhou, X.L.; Ke, M.Z.; Song, Z.J. Effect of Hypericum japonicum Thunb on the respiratory tract and systemic immune functions of rats. J. Guangxi Med. Univ. 2001, 18, 211-212.

46. World Health Organization. WHO general guidelines for methodologies on research and evaluation of traditional medicine. Available online: http://whqlibdoc.who.int/hq/2000/ WHO_EDM_TRM_2000.1.pdf (accessed on 22 February 2010).

47. Balasubramani, S.P.; Goraya, G.S.; Venkatasubramanian, P. Development of ITS sequence-based markers to distinguish Berberis. aristata DC. from B. lycium Royle and B. asiatica Roxb. 3 Biotech 2011, 1, 11-19.

48. Peng, W.; Wu, D.H.; Yang, L.W.; Wang, Y.G.; Li, P.B.; Su, W.W. Quality study of Hypericum japonicum Thunb. (Tianjihuang). Cent. South. Pharm. 2006, 4, 340-342.

49. Qin, S.Y.; Chen, X.H.; Mi, D.; Bi, K.S. RP-HPLC determination of isojacareubin in Hypericum japonicum Thunb. Chin. Pharm. Anal. 2007, 27, 718-720.

50. Xiong, L.; Liang, J.; Chen, X.H.; Ma, A.L.; Shen, Z.D.; Bi, K.S. HPLC determination of isojacareubin in Hypericum japonicum. Chin. Prac. Med. 2008, 3, 8-9.

51. Xiong, L.; Chen, X.H.; Cao, X.; Mao, Z.Y.; Bi, K.S. Content determination of quercetin-7-O- $\alpha$-Lrhamnoside in Hypericum japonicum by HPLC. J. Shenyang Pharm. Univ. 2008, 25, 806-809.

52. Wang, X.X.; Zhang, Y.P.; Feng, Y.Z.; Liang, G.Y. Content determination of quercetin in Hypericum japonicum by HPLC. J. Guiyang Coll. Trad. Chin. Med. 2009, 31, 18-20.

53. Yu, J.P.; Chen, Y.; Zheng, J.B. Determination of quercitrin in Hypericum japonicum Thunb. by HPLC. Chin. J. Mod. Appl. Pharm. 2009, 26, 499-500.

54. Xiong, L.; Chen, X.H.; Liang, J.; Bi, K.S. Simultaneous RP-HPLC determination of isoquercitrin, quercitrin and quercetin in Hypericum japonicum Thunb. Chin. Pharm. Anal. 2008, 28, 1619-1622.

55. Teng, J.L.; Ou, L.Y.; Tian, J.T. Simultaneous determination of quercetin, rutoside and isorhamnetin in Hyericum japonicum Thunb. by HPLC. Cent. South. Pharm. 2010, 8, 41-44.

56. Xiong, L.; Chen, X.H.; Liang, J. Simultaneous determination of contents of four flavonoids in Herba Hyperici Japonici by RP-HPLC. J. Shenyang Pharm. Univ. 2010, 27, 639-642.

57. Peng, W.; Wang, Y.G.; Su, W.W. Simultaneous quatitation of four flavonoids from Hypericum japonicum Thunb by HPLC. J. Chin. Med. Mater. 2011, 34, 1229-1231. 
58. Li, J.; Jiang, B.; Liu, X.; Zhang, J.; Chen, X.H.; Bi, K.S. Simultaneous determination of five bioactive flavonoids in Hypericum japonicum Thunb by high-performance liquid chromatography. Asian J. Trad. Med. 2007, 2, 75-81.

59. Su, J.; Fu, P.; Shen, Y.H.; Zhang, C.; Liang, M.J.; Liu, R.H.; Li, H.L.; Zhang, W.D. Simultaneous analysis of flavonoids from Hypericum japonicum Thunb. ex Murra (Hypericaceae) by HPLC-DAD-ESI/MS. J. Pharm. Biomed. Anal. 2008, 46, 342-348.

60. Lu, L.; Han, L.; Zou, L.S.; Liu, X.H. Analysis study on the flavonoids constituents in herba hyperici japonica by UPLC-MS. J. Nanjing Univ. Trad. Chin. Med. 2013, 29, 482-485.

61. Gao, W.N.; Luo, J.G.; Kong, L.Y. Quality evaluation of Hpericum japomicum by using high-performance liquid chromatography coupled with photodiode array detector and electrospray ionization tandem mass spectrometry. Biomed. Chromatogr. 2009, 23, 1022-1030.

62. Yang, L.W.; Wu, D.H.; Tang, X.; Peng, W.; Wang, X.R.; Ma, Y.; Su, W.W. Fingerprint quality control of Tianjihuang by high-performance liquid chromatography-photodiode array detection. J. Chromatogr. A 2005, 1070, 35-42.

63. US Food and Drug Administration. Food and Drug Administration Guidance for IndustryBotanical Drug Products (Draft Guidance); US Food and Drug Administration: Rockville, MD, USA, 2000; p. 4.

64. European Medicines Agency. Note for Guidance on Quality of Herbal Medicinal Products; European Medicines Agency: London, UK, 2001; p. 6.

65. State Food Drug Administration of China. Technical Requirements for the Development of Fingerprints of TCM Injections; State Food Drug Administration of China: Beijing, China, 2000.

66. Han, L.; Liu, X.H.; Wang, L.J.; Fu, X.S. Study on HSGC-MS fingerprint of Hyperici Japonici Herba. Chin. Med. J. Res. Prac. 2011, 25, 22-24.

67. Han, L.; Song, J.P.; Liu, X.H.; Li, J.S.; Cai, B.C.; Fu, X.S.; Lu, A.P. Studies on HPCE fingerprint of Herba Hyperici Japonici. Chin. J. Exp. Trad. Med. Form. 2011, 17, 104-107.

68. Li, J.; Wang, Z.W.; Zhang, L.; Liu, X.; Chen, X.H.; Bi, K.S. HPLC analysis and pharmacokinetic study of quercitrin and isoquercitrin in rat plasma after administration of Hypericum japonicum thunb. extract. Biomed. Chromatogr. 2008, 22, 374-378.

(C) 2014 by the authors; licensee MDPI, Basel, Switzerland. This article is an open access article distributed under the terms and conditions of the Creative Commons Attribution license (http://creativecommons.org/licenses/by/3.0/). 